\title{
OPTIMIZATION OF BARLEY MATURE EMBRYO REGENERATION AND COMPARISON WITH IMMATURE EMBRYOS OF LOCAL CULTIVARS
}

\author{
MARCELA GUBIŠOVÁ ${ }^{1,2}$, DANIEL MIHÁLIK ${ }^{1}$, JOZEF GUBIŠ $^{1}$ \\ ${ }^{1}$ Plant Production Research Institute Piešt'any, Plant Production Research Center \\ Piešt’any, Bratislavská cesta 122, SK-921 68 Pieštany, Slovak Republic \\ (gubisova@vurv.sk) \\ ${ }^{2}$ Department of Botany and Genetics, Faculty of Natural Sciences, Constantine the \\ Philosopher University in Nitra, Nábrežie mládeže 91, SK-949 74 Nitra, \\ Slovak Republic
}

\begin{abstract}
Regeneration ability of plant cells or tissues in explant culture is one of the key factors affecting success of genetic transformation. In experiments, the effect of explant type (whole embryo, scutellum, embryonic axis, meristematic/central zone of embryonic axis) and plant growth regulators (BAP or TDZ) on mature embryo regeneration was determined. Explant type significantly affected regeneration efficiency. While no regenerants were observed using mature scutella, whole embryos or embryonic axes produced the highest number of regenerants. Using embryonic axes with discarded apical and basal parts, regeneration efficiency dramatically decreased. No statistical differences in regeneration were observed between BAP and TDZ added to the regeneration medium in concentration 0.1 or $1 \mathrm{mg} \mathrm{l}^{-1}$. At last, regeneration ability of mature embryos of nine Slovak spring barley cultivars (Donaris, Ezer, Levan, Ludan, Nitran, Pribina, Sladar, Orbit, Pax) and Golden Promise as a model cultivar was examined and compared with regeneration ability of immature embryos which have been usually used for genetic transformation of barley. Although the regeneration from mature embryos was very weak, the same cultivars Golden Promise, Pribina and Levan showed the best regeneration ability by using both, immature and mature embryos. On the other hand, cultivars Ezer and Pax belonged to the weakest ones in both experiments.
\end{abstract}

Key words: BAP, barley regeneration, explant type, immature embryo, mature embryo, thidiazuron (TDZ)

\section{Introduction}

Regeneration ability of plant species in tissue culture is strongly affected by several factors, mainly by the species, genotype, explant type and its developmental stage and composition of culture medium. Likewise, the donor plant quality and environmental conditions have also a significant impact (DAHLEEN, 1999; KLČOVÁ et al., 2004). Immature scutellum has been the most widely used type of explant for genetic transformation of barley (WAN and LEMAUX, 1994; TINGAY et al., 1997; BARTLETT et al., 2008) because of its higher regeneration potential in the comparison with other explant types. However, there are efforts to improve regeneration ability of mature embryos (GANESHAN et al., 2003; SHARMA et al., 2004; SHARMA et al., 2005) for their availability throughout the year, avoiding the need for laborious growing of donor plants in controlled conditions and eliminating inter-seasonal variation. Choice of properly treated explant type and modification in media composition could provide the opportunity to achieve this aim. DAHLEEN (1995) described improvement of regeneration efficiency for barley immature embryos 
by increasing copper level; CHO et al. (1998) confirmed the positive effect of an intermediate cultivation medium containing BAP in combination with 2,4-D on induction of barley regeneration. Plant hormones play a significant role in culture medium. Until Dicamba (3,6-Dichloro-o-anisic acid) or 2,4-D (2,4Dichlorphenoxyacetic acid) are successfully used for callogenesis induction, BAP (6Benzylaminopurine) is usually used in regeneration media for barley. Several authors (SHAN et al., 2000; GANESHAN et al., 2003; SHARMA et al., 2004) described positive effect of addition of TDZ (thidiazuron) instead of BAP on plant regeneration. In this work, the effect of genotype, explant type and media composition on in vitro regeneration of barley from mature embryos was described.

\section{Materials and methods}

Mature seeds of two spring barley cultivars (Hordeum vulgare L.) Golden Promise (GP) and Orbit were used to determine the effect of explant type on in vitro regeneration ability. Seeds were surface sterilized by immersion in $70 \%$ alcohol for 2 min, then in $4 \%$ solution of sodium hypochlorite for $15 \mathrm{~min}$ with gentle shaking, and rinsed three times with sterile redistilled water. Then the seeds were left to imbibe for two days in sterile water with the addition of $6 \mathrm{mg} \mathrm{l}^{-1} 2,4-\mathrm{D}$ at $4{ }^{\circ} \mathrm{C}$ according to SHARMA et al. (2005). In the first experiment, four types of explants were aseptically prepared from this seeds: whole embryos (ES), sculella (S), embryonic axes (E) and embryonic axes with discarded apical and basal parts (EM, Fig. 1). For callogenesis and regeneration, modified media of SHARMA et al. (2004, 2005) were used (Tab. 1). After one week of culture, emerged shoots and roots were cut, so as not to inhibit callogenesis. Callogenesis took place four weeks on $\mathrm{J} 1$ medium in the dark at $25^{\circ} \mathrm{C}$, regeneration two weeks on $\mathrm{J} 2$ medium and next 3 weeks on $\mathrm{J} 3$ medium under the

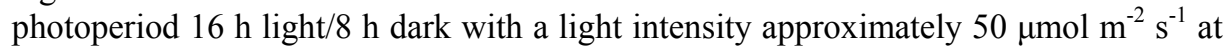
$25 / 20^{\circ} \mathrm{C}$.

In the second experiment, the effect of growth regulators BAP and TDZ on plant regeneration from embryonic axes of mature seeds of cultivars Golden Promise, Orbit and Levan were studied. Explants were cultivated as above, but medium J1 didn't contain BAP, medium J2 was omitted and medium J3 was supplemented with $1 \mathrm{mg} \mathrm{l}^{-1}$ 2,4-D and 0.1 or $1 \mathrm{mg} \mathrm{l}^{-1}$ BAP or TDZ. Calli were left to regenerate 5 weeks on J3 medium.

At last, regeneration efficiency of mature embryonic axes of 9 Slovak spring barley cultivars (Donaris, Ezer, Levan, Ludan, Nitran, Pribina, Sladar, Orbit, Pax) and a model cultivar Golden Promise was examined and compared with regeneration ability of immature embryos of the same cultivars. Regeneration process for mature embryonic axes was conducted as was mentioned above in the first experiment. Protocol for regeneration of immature embryos (scutella) has been described in GUBIŠOVÁ et al. (2011).

The frequency of callogenesis and regeneration (\%), number of regenerants per regenerating callus and efficiency of regeneration represented by the number of regenerants per plated explant were evaluated in all experiments. Experiments were repeated twice with 64 - 96 explants per each variant. Data were processed by one-way 
analysis of variance (ANOVA) followed by LSD test $(\alpha=0.05)$. Percentage data were transformed by $\arcsin \sqrt{ } \times$ before analysis.

Table 1. Composition of media for barley regeneration. Media were adjusted to $\mathrm{pH} 5.8$ and autoclaved at $121^{\circ} \mathrm{C}$ for $20 \mathrm{~min}$.

\begin{tabular}{|c|c|c|}
\hline J 1 & $\mathbf{J} 2$ & J 3 \\
\hline $4.3 \mathrm{~g} \mathrm{l}^{-1}$ MS (Murashige & $4.3 \mathrm{~g} \mathrm{l}^{-1} \mathrm{MS}$ (Murashige & $4.3 \mathrm{~g} \mathrm{l}^{-1} \mathrm{MS}$ (Murashige \\
\hline and Skoog, 1962) salts & a Skoog, 1962) salts & a Skoog, 1962) salts \\
\hline (Duchefa) & (Duchefa) & (Duchefa) \\
\hline $60 \mathrm{~g} \mathrm{l}^{-1}$ Maltose & $30 \mathrm{~g} \mathrm{l}^{-1}$ Maltose & $30 \mathrm{~g} \mathrm{l}^{-1}$ Maltose \\
\hline $1 \mathrm{~g} \mathrm{l}^{-1}$ Casein hydrolysate & $1.25 \mathrm{mg} \mathrm{l}^{-1} \mathrm{CuSO}_{4} .5 \mathrm{H}_{2} \mathrm{O}$ & $1.25 \mathrm{mg} \mathrm{l}^{-1} \mathrm{CuSO}_{4} .5 \mathrm{H}_{2} \mathrm{O}$ \\
\hline $1.25 \mathrm{mg} \mathrm{l}^{-1} \mathrm{CuSO}_{4} .5 \mathrm{H}_{2} \mathrm{O}$ & $500 \mathrm{mg} \mathrm{l}^{-1}$ Proline & $500 \mathrm{mg} \mathrm{l}^{-1}$ Glutamine \\
\hline $200 \mathrm{mg} \mathrm{l}^{-1}$ Myo-inozitol & $500 \mathrm{mg} \mathrm{l}^{-1}$ Glutamine & $200 \mathrm{mg} \mathrm{l}^{-1}$ Myo-inozitol \\
\hline $500 \mathrm{mg} \mathrm{l}^{-1}$ Proline & $200 \mathrm{mg} \mathrm{l}^{-1}$ Myo-inozitol & $1 \mathrm{mg} \mathrm{l}^{-1}$ Thiamine $\mathrm{HCl}$ \\
\hline $1 \mathrm{mg} \mathrm{l}^{-1}$ Thiamine $\mathrm{HCl}$ & $1 \mathrm{mg} \mathrm{l}^{-1}$ Thiamine $\mathrm{HCl}$ & $1 \mathrm{mg} \mathrm{l}^{-1} 2,4-\mathrm{D}$ \\
\hline $6 \mathrm{mg} \mathrm{l}^{-1} 2,4-\mathrm{D}$ & $6 \mathrm{mg} \mathrm{l}^{-1} 2,4-\mathrm{D}$ & $0.1 \mathrm{mg} \mathrm{l}^{-1} \mathrm{BAP}$ \\
\hline $0.001 \mathrm{mg} \mathrm{l}^{-1} \mathrm{BAP}$ & $0.01 \mathrm{mg} \mathrm{l}^{-1} \mathrm{BAP}$ & $2.5 \mathrm{~g} \mathrm{l}^{-1}$ Gelrite \\
\hline $3.0 \mathrm{~g} \mathrm{l}^{-1}$ Gelrite & $2.5 \mathrm{~g} \mathrm{l}^{-1}$ Gelrite & \\
\hline
\end{tabular}

\section{Results and discussion}

Comparing responses of different explant types of barley cultivars Golden Promise and Orbit significant differences were observed for frequency of callogenesis, regeneration and the number of regenerants. Mature scutella didn't produce any regenerants and frequency of callogenesis was also lower in comparison with other explant types (Fig. 2). SHARMA et al. (2005) observed no response of scutella also. In their experiments, scutella of cultivar GP didn't produce any callus, while $73 \%$ of scutela were callogenic in our experiments. Frequency of regeneration varied from $0 \%$ for mature scutella up to $89.7 \%$ for whole embryos of GP. Frequency of regeneration of whole embryos was higher for GP in comparison with cv. Orbit, although efficiency of regeneration of embryonic axes and embryonic axes with discarded apical and basal parts was similar for both cultivars. SHARMA et al. (2005) described that scutella inhibited callus proliferation of whole embryos. We didn't observe such effect and whole embryos of GP (Fig. 1) produced even more regenerants than embryonic axes alone. In the next experiments, embryonic axes were only used due to lower germination on induction medium. Embryonic axes with discarded apical and basal parts were used with the aim to eliminate germination of embryos in culture, but regeneration frequency of embryonic axes treated in this way dramatically decreased.

The effect of BAP or TDZ in concentration 0.1 or $1 \mathrm{mg} \mathrm{l}^{-1}$ on barley mature embryonic axes regeneration was studied in the second experiment. Although GANESHAN et al. (2003) and SHARMA et al. (2004) recommend using TDZ for regeneration of barley from meristematic shoot segments of mature embryos and SHAN et al. (2000) for immature embryos of barley, we didn't observe significant differences between TDZ and BAP in the frequency of regeneration and the number of regenerants from mature embryonic axes. There were only differences comparing $\mathrm{cv}$. GP (29.43\% regenerating callus; 0.56 regenerants per plated explant) with other two 
cultivars Orbit and Levan (15.33 and $16.46 \%$ regenerating explant respectively and 0.22 regenerants for both cultivars).
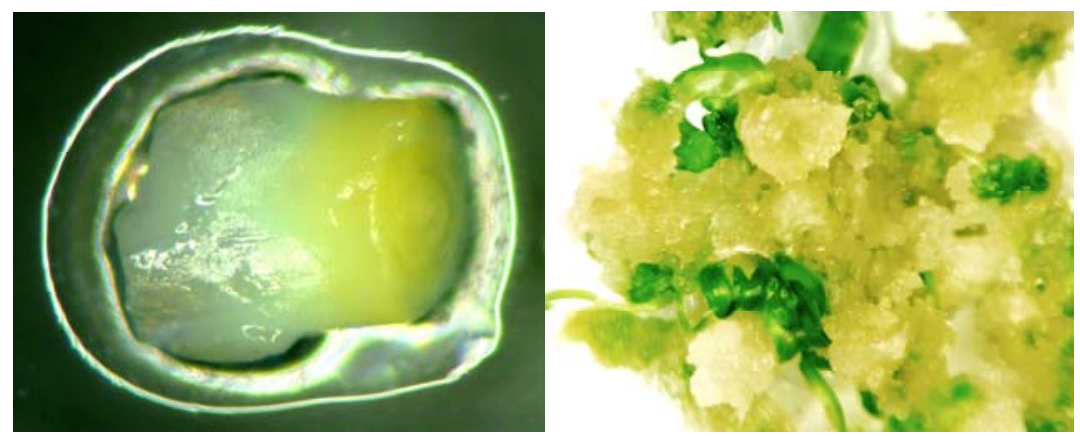

Fig. 1. Detail of barley embryonic axis with discarded apical and basal parts (left) and regeneration of cv. Golden Promise from whole mature embryo (right).

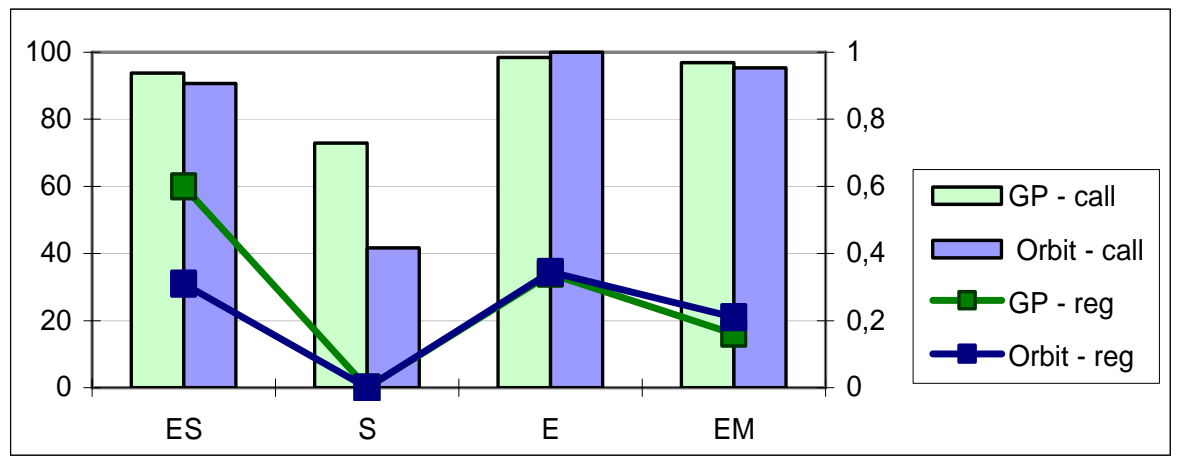

Fig. 2. Frequency (\%) of callogenic explants (call) and the number of regenerants (reg) per plated explant of four types of explants (whole embryo - ES, scutellum $-\mathrm{S}$, embryonic axis - E and embryonic axis with discarded apical and basal parts - EM) from mature seeds of spring barley cultivars Golden Promise and Orbit.

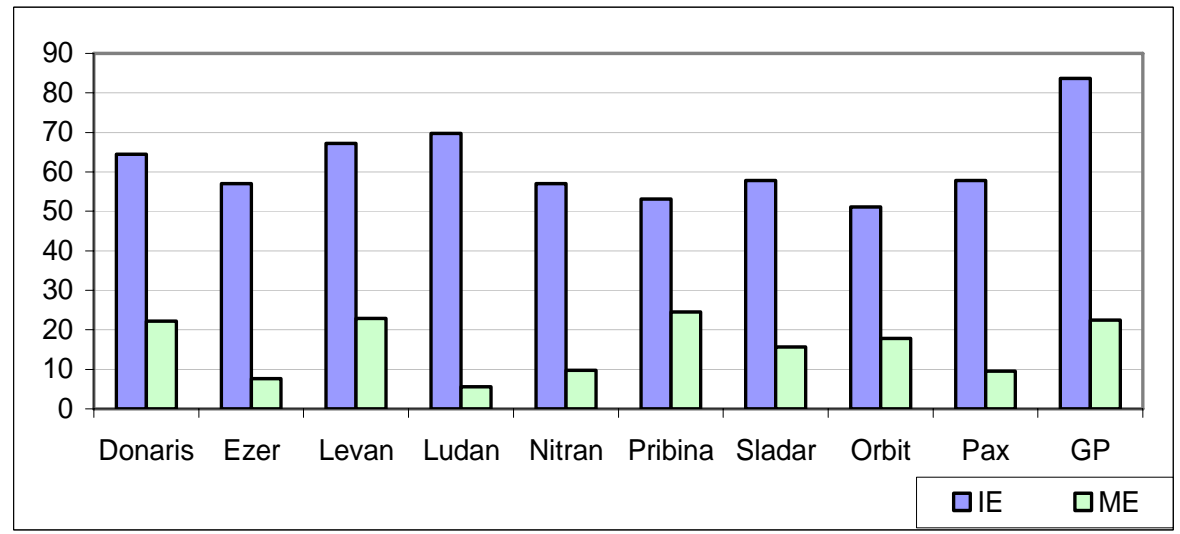

Fig. 3. Frequency (\%) of regenerating explants of Slovak spring barley cultivars and cv. Golden Promise using mature embryonic axes (ME) in comparison with immature scutella (IE) 
Statistically significant differences were observed comparing nine Slovak spring barley cultivars and cv. Golden Promise with respect to their frequency of regeneration and the number of regenerants. The best responses were observed for cv. Golden Promise and Pribina. Cultivar Pribina actually showed higher regeneration frequency and higher number of regenerants per regenerating callus than GP (Fig. 3, 4). These two cultivars and cv. Levan also showed the best regeneration ability in experiments with both, mature and immature embryos. On the other hand, Ezer and Pax were the weakest regenerating cultivars by using mature as well as immature embryos.

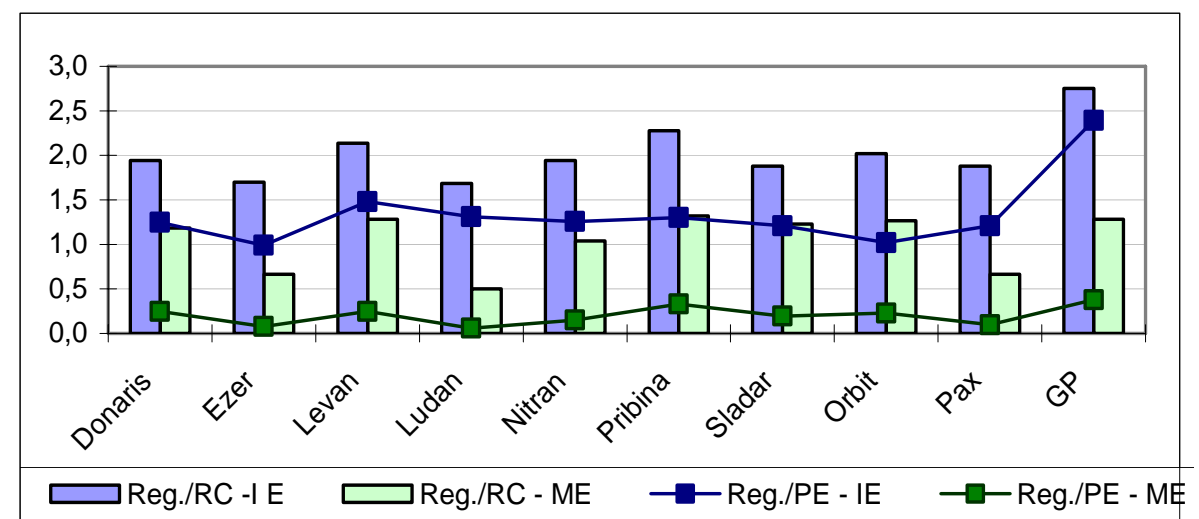

Fig. 4. Number of regenerants per regenerating callus (Reg./RC) and per plated explant (Reg./PE) of Slovak spring barley cultivars and cv. Golden Promise using mature embryonic axes (ME) in comparison with immature scutella (IE).

\section{Conclusions}

Finally, we can conclude that while scutella from immature embryos have good regeneration capacity, scutella from mature seeds are not regenerable. As for mature embryos, embryonic axes or whole embryos are suitable for regeneration in explant culture. Slovak cultivars of spring barley Pribina and Levan were chosen to be the most regenerable by using mature as well as immature embryos. Because the regeneration from mature embryos is still not effective and would need further investigations, immature scutella of chosen cultivars can be recommended for genetic transformation of barley.

Acknowledgements: This work was supported by Operational Programme Research and Development: Development of new types of genetically modified plants with farm traits (ITMS 26220220027) from European Regional Development Fund. We thank Mrs. Klára Križanová from Hordeum Ltd. Sládkovičovo for providing seeds of Slovak barley cultivars.

\section{References}

BARTLETT, J.G., ALVES, S.C., SMEDLEY, M., SNAPE, J.W., HARWOOD, W.A.: High-throughput Agrobacterium-mediated barley transformation. Plant Methods, 4 (22), 2008, http://www.plantmethods.com/content/4/1/22. 
CHO, M.J., JIANG, W., LEMAUX, P.G.: Transformation of recalcitrant barley cultivars through improvement of regenerability and decreased albinism. Plant Science, 138 (2), 1998, 229-244.

DAHLEEN, L.S.: Improved plant regeneration from barley callus cultures by increasing copper levels. Plant Cell Tiss.Org. Cult., 43, 1995, 267-269.

DAHLEEN, L.S.: Donor-plant environment effects on regeneration from barley embryo-derived callus. Crop Sci., 39, 1999, 682-685.

GANESHAN, S., BAGA, M., HARVEY, B.L., ROSSNAGEL, B.G., SCOLES, G.J., CHIBBAR, R.N.: Production of multiple shoots from thidiazuron-treated mature embryos and leaf-base/apical meristems of barley (Hordeum vulgare). Plant Cell Tiss. Org. Cult., 73, 2003, 57-64.

GUBIŠOVẢ, M., MIHÁLIK, D., KONÔPKOVÁ, L':: Regeneration efficiency of Slovak spring barley cultivars and winter wheat cultivars. Agriculture, 57 (2), 2011, 76-83.

KLČOVÁ, L., HAVRLENTOVÁ, M., FARAGÓ, J.: Cultivar and environmental conditions affect the morphogenic ability of barley (Hordeum vulgare) scutellumderived calli. Biologia, Bratislava, 59 (4), 2004, 501-504.

MURASHIGE, T., SKOOG, F.: A revised medium for rapid growth and bioassay with tobacco tissue cultures. Physiologia Plantarum, 15 (3), 1962, 473-479.

SHAN, X., Li, D., Ou, R.: Thidiazuron promotes in vitro regeneration of wheat and barley. In Vitro Cell. Dev. Biol.-Plant, 36, 2000, 207-210.

SHARMA, V.K., HANSCH, R.,. MENDEL, R.R, SCHULZE, J.: A highly efficient plant regeneration system through multiple shoot differentiation from commercial cultivars of barley (Hordeum vulgare L.) using meristematic shoot segments excised from germinated mature embryos. Plant Cell Rep., 23, 2004, 9-16.

SHARMA, V.K., HANSCH, R.,. MENDEL, R.R, SCHULZE, J.:Mature embryo axisbased high frequency somatic embryogenesis and plant regeneration from multiple cultivars of barley (Hordeum vulgare L.). J. Exp. Bot., 56 (417), 2005, 1913-1922.

TINGAY, S., McELROY, D., KALLA, R., FIEG, S., WANG, M., THORNTON, S., BRETTELL, R.: Agrobacterium tumefaciens-mediated barley transformation. The Plant Journal, 11 (6), 1997, 1369-1376.

WAN, Y., LEMAUX, P.G.: Generation of large number of independently transformed fertile barley plants. Plant Physiology, 104 (1), 1994, 37-48.

Presented at the 3rd International Scientific Conference "Applied Natural Sciences - 2011", October 5-7, 2011, Častá Papiernička, Slovak Republic. 